\title{
AN ONLINE ENGLISH TEACHING EXPERIENCE DURING COVID-19 PANDEMIC: PRELIMINARY FINDINGS
}

\author{
Sergio Alonso Lopera Medina \\ Universidad de Antioquia (Colombia) \\ sergio.lopera@udea.edu.co
}

Received: 26/04/2020 - Approved: 19/06/2020 - Published: 30/07/2021

DOI: doi.org/10.17533/udea.lyl.n80a13

\begin{abstract}
This article presents the preliminary results of an Emergency Remote Teaching (ERT) experience (Hodges, Moore, Lockee, Trust \& Bond, 2020) of a foreign language professor during the COVID-19 pandemic. Using a qualitative methodology, technological and educational obstacles were found, such as participation in videoconferences, the implementation of real tasks, the use of humor and the motivation of students. It is concluded that the lecturer gained confidence and expertise in an interactive environment. Finally, the promotion of interaction and alternative and formative evaluation in class is recommended.
\end{abstract}

Key words: emergency remote teaching (ERT); COVID-19; teaching English; online teaching; foreign language.

\section{UNA EXPERIENCIA DE ENSEÑANZA DE INGLÉS EN LÍNEA DURANTE LA PANDEMIA DEL COVID-19: RESULTADOS PRELIMINARES}

Resumen: Este artículo presenta los resultados preliminares de una experiencia de enseñanza remota de emergencia (ERT) (Hodges, Moore, Lockee, Trust \& Bond, 2020) de un profesor de lengua extranjera durante la pandemia del covid-19. A partir de una metodología cualitativa, se hallaron obstáculos tecnológicos y educativos, como la participación en las videoconferencias, la implementación de tareas reales, el uso del humor y la motivación de los estudiantes. Se concluye que el profesor ganó confianza y experticia en un ambiente interactivo. Finalmente, se recomienda la promoción de la interacción y la evaluación alternativa y formativa en clase.

Palabras clave: enseñanza remota de emergencia (ERT); covid-19; enseñanza de inglés; enseñanza en línea; lengua extranjera. 


\section{Introduction}

7 he world has faced a respiratory syndrome, which has caused different governments to make decisions in order to control the coronavirus disease 2019 (Covid-19). This virus emerged in the city of Wuhan,

L China, in December 19 and since then not only China had to set some unprecedented strategies that aimed at regulating the progression of this disease, but also different countries around the world. Closing academic institutions and workplaces, canceling concerts and airline tickets, avoiding crowded places, handwashing, wearing masks, and keeping distance from each other were just some the decisions made by different nations. Governors also used quarantines to stop the spread of the disease and led many people to work from home. In the field of education, many institutions moved their face-to-face modality to online modality as a way to maintain the education process active.

Redmon (2011) stated that the change from face-to-face modality to online modality challenges the expectations in both teachers and students. Teachers may even feel that this shift is confronting them and their identities are at risk. Thus, teachers have to redefine their teaching practices and take some training as the nature of changes in online modality. Management, pedagogical approaches, content knowledge, technical skills, assessment of the course, and the ability to support the social and emotional well-being of students are some of the skills for effective online teachers. Moreover, social presence is a key element in online environments, due to the fact that participants have to project their personal characteristics as real people who are present in this modality (Garrison, Anderson, \& Archer, 2001). Besides, Esani (2010) recommended creating a learner-centered environment, adjusting teaching practices, developing creativity, and encouraging knowledge sharing in the shift from face-toface modality to online environment.

Although literature supports some academic and technological issues to consider moving from face-toface modality to online modality, many teachers were confronted to do it without any preparation as a result of Covid-19. In fact, as a foreign language English professor who was used to teaching face-to-face courses and was suddenly asked to teach from home via online, this paper deals with a new and short online teaching experience during the Covid-19 quarantine. The research question that guided the inquiry is: What are the results of a new online teaching experience in a foreign language communicative course? So, this article begins with the review of literature and the methodology. Then, data collection instrument and context are given. Finally, findings, conclusions, recommendations, and limitations are presented. 


\section{Review of literature}

\subsection{Online/distance teaching}

Ossiannilsson (2017) argued that different educational terms, such as online learning, web-based learning, e-learning, blended learning, virtual learning, among others, have appeared since the introduction of the digital technology, but all these terms have to do with distance education. Moore and Kearsley (2012) defined distance education as «teaching and planned learning in which the teaching normally occurs in a different place from the learning, requiring communication through technologies as well as special institutional organization» (p. 2) xxx). However, the incorporation of software and content management systems changed the traditional idea of distance learning (Ossiannilsson, 2017) and learning is mostly given using a computer.

Hockly (2015) set the limits of online learning, as she argued that this involves fully online learning. In this modality, students learn the language totally online via internet, so there is no any face-to-face component. Different studies have contributed to name some of the advantages and benefits of online learning (Arkorful \& Abaidoo, 2014; Weiner, 2003; McDonald, 2001; Chen et al., 2005; Algahtani, 2011; Bowen, 2013; Lorenzetti, 2013; Hameed et al., 2008). Arkorful \& Abaidoo (2014), and MacDonald (2001) supported the following online learning advantages:

-Flexibility of time and place.

-Access to a huge amount of information.

-Opportunities to interact and have discussions among participants.

-Many students can attend classes.

-Individual learning differences are taken into account.

- Own construction of knowledge.

-All participants contribute to learning.

- Sense of community is given as activities encourage cooperation.

- This modality helps administrators compensate difficulties regarding academic staff.

- Self-pacing is given in this modality.

Finally, different authors have described and highlighted the importance of online learning, but the pandemic has caused to establish some differences between remote and online learning.

\subsection{Emergency remote teaching and online learning}

Hodges, Moore, Lockee, Trust, \& Bond (2020) highlighted the difference between well planned online learning and online learning in pandemic times. The authors stated that many universities had to cancel face-to- 


\section{An Online English Teaching Experience during Covid-19 Pandemic: Preliminary Findings}

face classes and move their meetings suddenly via online, in order to prevent the spread of Covid-19. Thus, the authors recommended teachers to differentiate between online learning and Emergency Remote Teaching (ERT). Although the faculty may support or improvise online teaching practices for those inexperienced professors, stress is being part of the process. This is understandable as the preparation of an online course may take about 9 months and professors are trained to teach using the internet. This is not the case in pandemic times. So, many educators must move their face-to-face course to online modality without any preparation or just with some guidance or advice given by the faculty members, who are expert on that field. Problems such as lack of preparation, timeconsuming, and negative feelings are some of the symptoms that an inexperienced instructor on distance work may face on the move.

On the other hand, Hodges et al. (2020) introduced the notion of ERT as a way to respond to the Covid-19 adversities, in which many face-to-face teachers have become online teachers without any experience. The authors support that ERT is a temporary teaching change of instructional delivery as a result of crisis reasons. The objective of this form of teaching is to provide students temporary access to learn or attend classes during the Covid-19 emergency. Previous teaching strategies such as the use of DVDs and radio education have been part of the solutions in times where education has been disruptive by conflict and violence in Afghanistan (Davies \& Bentrovato, 2011, cited in Hodges et al., 2020). Thus, the authors highlight the importance of finding ways to meet the institutional need in this Covid-19 time, and educational institutions have to look for teaching ways to support learners during a crisis. One of the options to consider is to create a Universal Design for Learning (UDL), with the purpose to design flexible, inclusive, and student-centered learning environments in order to give access to students for course materials, tasks, and assignments. Based on Stufflebeam \& Zhang (2017) Hodges et al. (2020) suggested the following evaluation model for the ERT: Context, Inputs, Process, and Products (CIPP):

-Context evaluations: participants assess not only needs, assets, and opportunities but also relevant contextual conditions and dynamics.

-Input evaluations: participants evaluate an action plan, the strategy of a program, the arrangements of staff, and budget in order to verify the effectiveness and the achievements of objectives.

-Process evaluations: participants monitor, document, assess, and report the plans implementations.

-Product evaluations: participants have to identify and assess costs and achievements in both short- and long-term ones.

Moreover, Hodges et al. (2020) recommended the following issues to consider in this Covid-19 time connected to the previous model: internal and external resources, responsibility of participants, technology infrastructure, support from experts, enhance opportunities for immediate and flexible learning demands, problems faced and results given. However, ETR should be focused on the context, input, and process rather than the product. 


\subsection{Previous studies}

Drouin (2012) and Benton \& Cashin (2012) supported that both face-to-face learning and online learning share some similarities. Interactions between student-student and teacher-student, teacher's support and mentoring, the quality of content delivery, and the presentations of contents are some of the similarities. Moreover, Reisetter et al. (2007) compared the quality of students' learning and found no differences between these two modalities. Szeto (2014) and Lopera (2014) also found that learners achieved similar learning results in both face-to-face modality and online modality. On the other hand, different studies support that these two modalities present some characteristics (Stacey \& Wiesenberg, 2007; Stern, 2004; Paskey, 2001; Szeto, 2011; Creasman, 2012; Ananga \& Kofi, 2017; Brown \& Liedholm, 2002; Brabazon, 2012; Dykman \& Davis, 2008; Lopera, 2014). Creasman (2012) found that online learning has some features that include asynchronous activity, non-linear discussions, and communication is much given through written texts and emails. Stern (2004) compared a course offered in faceto-face and online formats and detected that time consumption was a concern and students with more proficiency level regarding reading and writing skills scored better in online format. In another study, Solimeno et al. (2008) identified that asynchronous collaborative learning may lead to develop professional competences. Moreover, Berge (1995) and Kosak et al. (2004) reported that face-to-face teachers acquire new skills and competences when they teach online courses. Finally, Scagnoli, Buki and Johnson (2009) examined the pedagogical practices transfer of four teachers from online to face-to-face teaching and discovered that their perception changed in terms of online pedagogical strategies. They also found that transfer to physical classrooms is a complex process due to the teaching style.

As the previous studies have shown, some researchers have found both similarities and differences when comparing modalities. It is worth noting that both modalities have had time to prepare their courses, but this is not the case in pandemic times and it is worth describing an ERT experience.

\section{Methodology}

This practice is based on qualitative research, (Creswell, 2014; Yin, 2003; Merriam, 1998) more specifically a case study, as it was intended to describe and support the results of an experience in a real and new context, in order to make sense of an ERT practice (Denzin \& Lincoln, 2018) during Covid-19 pandemic. It was also intended to share the feelings of the participants as a way to describe their experiences. In other words, this is a case study with an interpretative approach (Stake, 1998), as the objective is to describe real-life situations in a new educational experience. Before proceeding with this study, participants signed a consent form accepting to participate voluntarily. 


\subsection{Data collection instruments}

The video recordings and the professor's journal were the instruments used to gather data from the lessons given during the Covid-19 quarantine. In this sense, Creswell (2012) supported that documents are very helpful in research processes, since they help investigators understand the studied phenomena.

\subsection{Context}

The ERT experience exposed here during the Covid-19 quarantine began on March 19, 2020 and it is still going on. Participants are a group of beginners (A2 level) in a public university in Medellín (Colombia). Twentyone undergraduate students aged 18 to 22 from the Pharmaceutical Chemistry program attend the course. The course usually lasts 64 hours per semester, but after the change to online modality, only 20 hours were face-to-face and two out of three units of the course were fulfilled. It is important to mention that the objective of the course is to prepare students for basic interactions by providing personal information and identifying the main ideas and specific information in oral and written texts. About the methodology of the English program, this follows the communicative approach (Canale \& Swain, 1980; Celce-Murcia, Dornyei \& Thurrell, 1995; Instituto Cervantes, 2002; Savignon, 2001), as the objective is to prepare students to develop skills to communicate successfully. The methodology is also based on the principles of Task-Based Language Teaching (TBLT) (Ellis, 2003; van den Branden, 2006) due to the fact that learners have to accomplish meaningful tasks using the target language.

\section{Findings}

The results of the ERT experience during the Covid-19 quarantine are explained in two categories: technological issues and teaching matters.

\subsection{Technological issues}

The English professor took a short course on teaching through the platform Moodle in 2008 and participated in the design of a foreign language reading comprehension course in the same year using this platform. He was also part of a research group who investigated the effects of teaching a foreign language reading course by using the aforementioned platform. This past experience helped him gain some confidence working on the virtual modality with a new challenge: teach English fully online without any previous time of lesson planning. In his previous experience, different members helped him out designing the activities, setting the platform, and arranging pedagogical issues without any pressure. However, things are now totally different and he had to improvise different actions in order to respond to the ERT during Covid-19 time. The first action he did was to ask an expert 
An Online English Teaching Experience during Covid-19 Pandemic: Preliminary Findings

for a quick help in order to select a tool or a program to teach his classes via online. One of his colleagues has a lot of experience teaching language courses online and advised him in about 10 minutes to use only one of the tools the university email account offers: Google Meet. This service offers recordable video conferences and chat interaction for up to 250 participants. Finally, he showed him how to set an invitation for a class and gave him a sample of the interface.

The second action was to attend a couple of virtual conferences given by the university staff in order to prepare face-to-face educators for online teaching. The first conference was an introduction of the virtual teaching world, while the second one was about the use of interactive tools. Although these conferences were useful, he still felt afraid of facing the online teaching world. So, the following day, he invited his students to have their first online class on March 19, 2020 and programmed it on Google Calendar (see Image 1). Then, he also sent an email, in which he reminded them the online invitation and asked them two questions whether they had computers or internet access. Only three students out of 21 responded affirmatively.

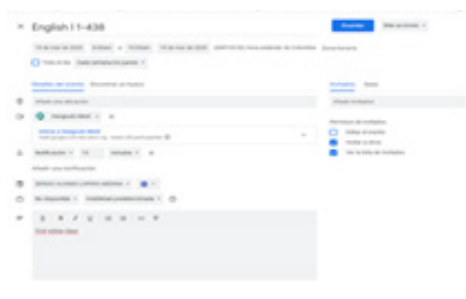

\section{Image 1. Invitation to the first online class}

The final action was learning by doing. Li (2015) and Likitrattanaporn (2017) supported that learning by doing is an effective approach that benefits participants as they try and discover new things. So, once the English professor logged in, he was eager to face the challenge to teach via online, even if only three students were available to participate in the lesson. However, when he was in his first online class, he found out that there were four participants connected at the beginning, as shown in Image 2.

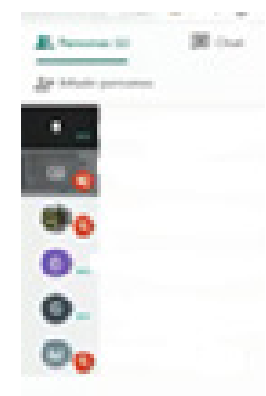

Image 2. List of participants of the English class on Google Meet 
Once the lesson started, the English professor asked his students if they had all received his invitation to have online English classes during the Covid-19 quarantine, and they assented. However, one of the students commented that not all of the class received the Google Calendar invitation via email as she was chatting with one of her classmates through WhatsApp. Then, one of the students suggested to resend the invitation by using the Google Meet chat service. The instructor, instead, suggested his students to resend the invitation they four had received to all their classmates as a way to make sure to have all participants in the online session. As a result of that action, eleven students joined the first class. It is worth noting that such problem has been present in all sessions, so they have applied the same strategy. The English tutor has also sent different emails to the people in charge of the online university service stating the aforementioned problem. Turning off the microphones and the camera if someone is not participating, using the chat to ask questions or making comments, finding a quiet place at home for studying, and staying healthy were some of the recommendations given. So, he also told his students that all online classes were going to be recorded if someone needed to watch them again.

During the Covid-19 teaching experience, the English professor has also encountered two main technological problems: firstly, the low quality of sound when sharing videos on screen on Google Meet. Although sometimes the instructor included the visit of some websites or YouTube videos in his lessons, his students could not hear the sound of the videos, so he had to ask them to play the video in their own computers as a strategy to solve this difficulty. Secondly, the activation of some students' microphones. When the educator asked some students to answer some specific questions, they were not able to do so, since they could not turn on their microphones or had further technical troubles with their computers. Nevertheless, the tutor told them to use the chat for participating in the online sessions. An average of 3 and 4 students per online class have had this problem, which was registered on the professor's diary.

\subsection{Teaching matters}

Although the English professor has some experience about teaching EFL reading virtually (Osorno \& Lopera, 2012) and has given lessons asynchronously, it is worth noting that it was his first experience fully online in a pandemic time and following the principles of communicative approach. As mentioned above, he attended a conference about an introduction of the online teaching world, in which it was recommended to lessen students' anxiety to face online classes. So, the first strategy the instructor used was to contact his students via email in Spanish, in order to ask them if they had computers and internet access to connect to online classes during the Covid-19 quarantine. He also asked them to make suggestions for completing the remaining topics of the course (English 1) during this period. However, only three students confirmed their accessibility and did not proposed any solution. Finally, the tutor tried to be understanding, available and flexible. Also, he stated that he was going 


\section{An Online English Teaching Experience during Covid-19 Pandemic: Preliminary Findings}

to be online during all virtual sessions or at any moment, by setting personal online classes and sending reminders or emails to lessen anxiety.

The second strategy was given in the first English online class with a warming and informal greeting: «Hey, hi guys, nice to see you around [smiling].» The four students who were present at the beginning smiled back and replied to his salutation: «Hi, teacher, good morning; hi; hello! hey, teacher! » Then, the English professor switched into Spanish in order to lessen anxiety, too. He thanked them to be present and motivated them to do their very best during the Covid-19 quarantine. After that, the group decided to wait for about 10 minutes for other students to get connected. Meanwhile, they kept on talking about the new class modality and their feelings to avoid silence, expressed in words like «I feel weird,» «I am stressed,» «I am OK,» and «I'm a little nervous.» Later, seven more students joined the class and the tutor welcomed them and began his class. The first action he did was to show them how to use the different icons or options the interface offers and to solve some of the difficulties they had to log in. So, the professor's role was to solve technical problems (Muñoz \& González, 2010) at the very beginning. Then, he shared the class the agenda of the session as it is shown in Image 3.

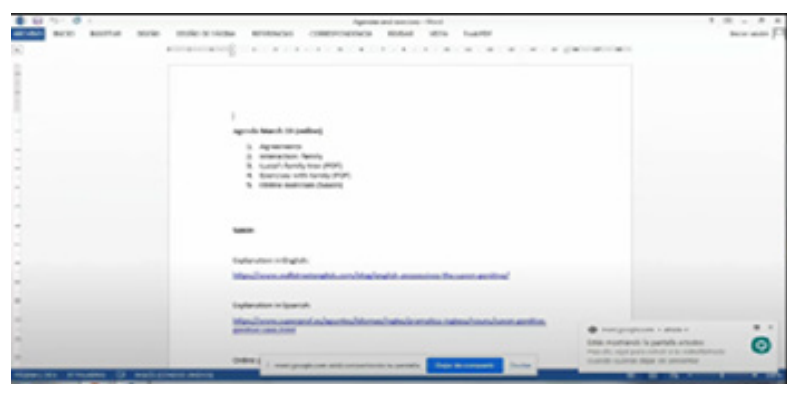

Image 3. Agenda of the English class

However, it is important to mention that the English professor had previously sent the agenda as well as the reminder for that class session via email. After that, the educator began the class by mentioning the topics in English. Firstly, he talked about the course agreements. The instructor and his class discussed about the exact time for starting the classes, the way of interaction, the evaluation process, and the participation during the online sessions. Later, they continued with the topics of the unit and one of them was about family. Having a chilled class atmosphere and as a matter of example, the tutor began to talk about his own family. He then asked some students to speak about their families, too. As a way to have some humor in the online class, the professor chose randomly some volunteers to describe their families: «Any volunteer? Yes, Peter you are my first volunteer, ha, ha, ha! » Then, he greeted and welcomed a dog to the session when one of the students was describing her family members and the class could hear when it barked close to her. Then, the class continued with the completion of oral exercises as he was used to doing it in face-to-face sessions. Moreover, when they mispronounced a word, the instructor immediately corrected them. However, some students could not participate because they had technical problems with their microphones. Finally, before class finished, the English professor asked students about their 
An Online English Teaching Experience during Covid-19 Pandemic: Preliminary Findings

reactions and feelings regarding the first online session: «An interesting class,» «a new experience,» «covering of topics,» «lack of interaction among participants,» «lack of participation of some participants due to microphone problems,» and «verify Google Meet invitations» were some of the students' comments.

When the online class was over, the English professor wrote some comments on his diary. One of them was about the length of time to prepare his classes:

It took me more time than expected to prepare my class in order to make sure that everything was going to work properly: following the agenda of the class, not to be lost using the interface, lessen students' anxiety, take into account their recommendations, check Google Meet invitations, as well as participation. I even had a short rehearsal to teach my first class (Diary, entry 1).

It is worth stating that time-consuming is part of this modality and it is supported by different authors (Bates \& Sangra, 2011; Guri-Rosenblit, 2018; Pineda \& Tamayo, 2016). The second entry of the professor's diary was about the teaching process during his first class. «I did not feel quite confident in this modality and I concluded that this was natural as I was used to teaching face-to-face modality and things take some time to accommodate» (Diary, entry 2). The third comment was about making corrections when students make mistakes. «I felt that this does work properly and that I had to improve this» (Diary, entry 3 ). The following comment was about the use of humor in class, which the English tutor concluded that he used it spontaneously as a way to call students' attention or to make them feel comfortable (Bakar \& Kumar, 2019). Finally, he gave a thought about some moments of silence, since students took more time to respond or interact and he perceived that as a negative aspect.

For the second online class during the Covid-19 quarantine, the English professor repeated mostly the same actions of the previous session: he invited his students via Google Calendar and sent an email reminder with the class agenda attached. Once students got connected, the educator welcomed each student enthusiastically and began the class. At the beginning there were 6 students out of 21 . So, the tutor used humor again as a warm-up. He was drinking a cup of coffee and he placed his mug close to the camera. Then, the educator invited them to drink it and students thanked him via chat: «ha, ha, ha!» and «thank you, teacher.» Then, the tutor read the agenda for the class and took some time to give them some advice in Spanish about the new modality that included patience, exploration, participation, and effort to attend the sessions. After that, he continued with the class in English and asked some students to participate by answering some of the questions.

The main task for Unit 2 was to respond to an email that a guest sent asking students about the people they live with and the place they live in. One of the tasks was to ask for and respond information about family members. Then, the English professor tried a new form of interaction: he asked a couple of students to interact each other, in which one of them asked questions about family members and the other one responded by using the interface. In this activity, the educator was not the center of the class, so he had lessened the pressure of his responsibility. On the other hand, it is important to mention that faculty professors base their practices on a material designed by the English university program, which include exercises such as matching, filling in the blanks, listening activities, and writing tasks. Based on that, the tutor asked his students to complete some of them. During that silence time, 


\section{An Online English Teaching Experience during Covid-19 Pandemic: Preliminary Findings}

he felt that something was missing. However, he did not do anything about it and continued with the online class as usual. Afterwards, when the tutor was watching again the recording of the second session, he noticed two things: he had incorporated one of his didactic strategies by using a Word file as a board (blackboard), as it is shown in Image 4.

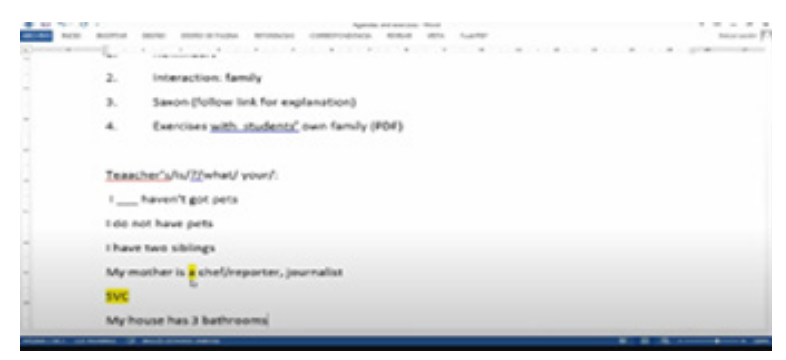

Image 4. Didactic strategy in the English class

The second thing is that the English professor always kept his camera on, and he concluded that it was a good strategy, as students might feel accompanied. On the other hand, he still corrected students' mistakes. When the class was about to finish, the educator asked his students to share their feelings and comments on the second experience, from which more positive comments were given: «I felt fine,» «The class was OK,» and «participation was present.» In contrast, one of the students reported that she did not receive the Google Meet invitation to join the class due to technical difficulties.

Again, when the online class was over, the English professor wrote some comments on his diary. The first comment involves his confidence in this new modality. Although he felt a little better in this second session, he did not feel that much confident either. The second comment is about the instant correction when students made mistakes, but the tutor did not take this into account. The third observation deals with the camera, as he always appeared on the video. He concluded that this is fine, since they are used to attending face-to-face classes under a traditional teaching, in which the educator is the center of the class and they need to feel guided. Finally, the tutor wrote an entry about his impressions about the quiet moments of the interactions.

Until the present time (April 17, 2020), the English professor has taught 8 online classes and he has followed the same strategies like the ones mentioned above. However, he still has to outline some different aspects in his ERT experience during the Covid-19 quarantine. The first one involves the use of the camera. As mentioned before, the main task for Unit 2 was to reply an email by describing the family members and their neighborhoods. So, the educator used the camera to describe his own house as a sample of a real pedagogical task. He also raised awareness about local culture features, such as typical objects, colloquial language expressions or family customs. In fact, the tutor showed his students a typical accesory of Antioquia called carriel $^{1}$ (see Image 5). So, he asked students to look for objects or some actions that may represent their cultures. In this sense, Byram (1997) stated that curiosity may lead participants to an understanding of the people's culture. As a result, one of the students,

1. A carry-all bag that local farmers and muleskinners used to wearing. Inside of them, they may carry pocket knives, religious images, combs, pocket mirrors, family photos, among other objects, as part of their rural identity. 
An Online English Teaching Experience during Covid-19 Pandemic: Preliminary Findings

who lives close to the Colombian Atlantic Coast, described her house and showed a sombrero vueltiao hat —also depicted in Image 5-. She mentioned that vueltiao hats are made by farmers or indigenous people in that zone. She also mentioned that Vallenato music and vueltiao hats are the best combination that represent her culture.

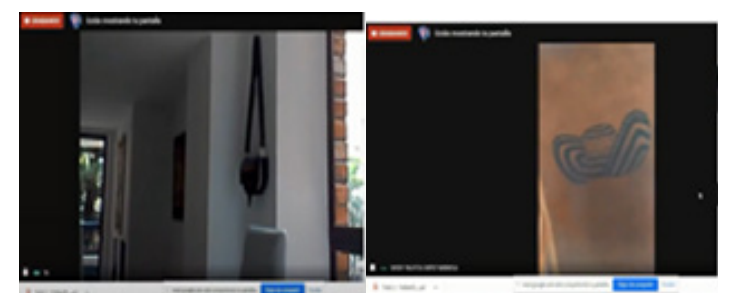

Image 5. Typical objects shown during the English class

The second aspect to mention is the inclusion of speaking and reading activities that involve things to do during Covid-19 quarantine. As a warming activity before working with a reading, the English professor asked them to describe some of their leisure-time activities during the pandemic. Listening to music, watching movies or series, and practicing indoor sports were the most outstanding ones. Then, the instructor asked his students to open a link that contains a reading about relaxing activities ${ }^{2}$ and did some scanning activities. At the end, the instructor asked some students to read aloud the text. He then took notes on his diary about this activity and concluded that practicing English has to lead to a meaningful experience for students. He also concluded that it is vital to use materials that might help students improve their mental health and also motivate them to connect to virtual classes.

The third element to mention was the English professor's effort to encourage his students to connect to online classes. So, he asked his learners to watch a video ${ }^{3}$ that motivates students to understand the situation of the Covid-19 quarantine and maintain the school open — the online one-. Then, the class shared some perceptions about it in Spanish. The comments can be related to the roles and compromises as international citizens or citizens of the whole world (Nusbaum, 2002). In short, learning to live in a quarantine time and maintaining the schools open are part of the responsibilities that guarantee the existence of humankind.

Regarding the fourth aspect, one achievement was that the English professor gained confidence for teaching via online. In fact, he tried new resources as he asked students to search for information about different types of houses on the internet and share their screens with their findings. The instructor was also able to control time to complete an activity by asking his students to work in pairs and use Google Hangouts. Thus, in one of the entries of the professor's diary, he wrote: «I feel now much better in this modality and I am getting used to it. I am also trying new things» (Diary, entry 10). From that, he concluded that he has learned by doing (Li, 2015; Likitrattanaporn,

\footnotetext{
2. https://www.cnbc.com/2020/03/20/relaxing-activities-to-do-at-home-during-covid-19-quarantine.html

3. https://www.youtube.com/watch?v=6W1e9edvk34
} 
An Online English Teaching Experience during Covid-19 Pandemic: Preliminary Findings

2017). He also noticed that he had improved an issue in his ERT practices: he did not make instant correction when students made mistakes. The following aspect was the role of the students reluctant to interact during online classes. Some students commented that they had technical problems with their microphones and could not answer some of the oral questions or complete the activities the instructor assigned in a specific moment. In this sense, the tutor believed that the students' microphones were fine but they did not have any intention to activate them and speak. However, this affirmation cannot be validated so far. Thus, in order to overcome that technical problem, the professor asked them to respond by using the chat. The last aspect to mention is that the instructor also had the sensation that he taught on this modality as if he was in face-face education. Nevertheless, previous studies have shown that both face-to-face modality and online modality share some similarities (Drouin, 2012; Benton \& Cashin, 2012; Reisetter et al., 2007) and this may have happened to the English instructor in his ERT experience exposed in this paper.

\section{Conclusions}

Due to the threat of Covid-19, many educational centers were forced to change their face-to-face classes to online education suddenly. In this paper, a new experience teaching English via online to a group of foreign language beginners was shared. Because it was a quick modality move, the English professor had to try new strategies that gave him some experience in his ERT (Hodges et al., 2020). One of the results of the experience is that he learnt by doing (Li, 2015; Likitrattanaporn, 2017). Using new resources, controlling time, asking students to work in pair using Google Hangouts were some of the actions learnt. Another aspect has to do with his attitude to try a new modality without much experience. Face-to-face education has still a lot of benefits reported by different studies and scholars have accomplished a lot of advances in the academic field for years. Thus, most language educators still reject to try new teaching approaches and methods, as a consequence of receiving a traditional education. Confidence gaining was the result of the aforementioned actions and now the tutor feels more comfortable working via online

One of the aspects of this teaching experience during Covid-19 quarantine is that culture plays an important role in language interactions. On the one hand, humor was present in some sessions of class, which is an essential aspect in social interactions (Lopera, 2016). On the other hand, silent times were reported at some moments of the class sessions, which made the tutor feel uncomfortable. In this sense it can be said that participants conceive humor as a positive element in social interactions and perceive silence negatively (Haverkate, 2004). However, silence in this context cannot be perceived as a negative element as leaners need time to do pedagogical activities.

The final conclusion is that this ERT experience was framed into the Context-Input-Process-Product model (CIPP) (Stufflebeam \& Zhang, 2017), since the English teacher assessed the students' needs and opportunities:

-Context: After asking a colleague for help, the tutor surveyed his students on technological access and set an action plan. 
An Online English Teaching Experience during Covid-19 Pandemic: Preliminary Findings

-Input: In order to teach on virtual modality and learning by doing, the tutor did research and monitored himself along the process.

-Process: When documenting his practice, the tutor reflected about his work and gained experience teaching online.

-Product: The tutor identified the outcomes of his course.

\section{Recommendations and limitations}

One of the recommendations for second language teachers has to do with participants' interactions during Covid-19 class sessions. The course follows the communicative approach and it is essential that students speak, write, listen, and read. The Google Meet service allows not only participants to use these four skills but also to work in groups. Thus, language educators need to design activities that promote interaction among participants. The second recommendation for language tutors is to make sure that all students participate, even though they have technical difficulties. Chatting is a good option in that case. Another suggestion for tutors is to rethink about evaluation and consider including both alternative and formative assessment. Self-assessment, peer-assessment, take-home exams, open-book exams, and small group exams are solutions to take into account (Shohammy, 2001; Picón, 2013; Bengtsson, 2019; Garfield, 1993; Doghonadze \& Demir, 2013). Educators can even give a good score to those students who frequently participate in online sessions, leading to learners' extrinsic motivation. Besides, tutors should let students use any kind of learning resource or material. Finally, teachers may worry about cheating but the awareness of an ethical education system (Ramberg and Modin,2019), the search for the citizens of the whole world (Nusbaum, 2002) and the lead of the teachers have to be present in this Emergency Remote Teaching experience.

In this paper, an online teaching experience of 8 sessions was shared and the results might be affected when analyzing the whole process. Also, the English professor used only two instruments to gather data which might affect the reliability of the results. 


\section{Bibliographical references}

1. Algahtani, A. F. (2011). Evaluating the Effectiveness of the e-Learning Experience in Some Universities in Saudi Arabia from Male Students' Perceptions. (Durham theses), Durham University.

2. Ananga, P. \& Kofi, I. (2017). Comparing Face-to Face and Online Teaching and Learning in Higher Education. MIER Journal of Educational Studies, Trends \& Practices, 7(2), 165-179.

3. Arkorful, V. \& Abaidoo, N. (2014). The Role of e-Learning, the Advantages and Disadvantages of Its Adoption in Higher Education. International Journal of Education and Research, 2(12), 397-410.

4. Bakar, F. \& Kumar, V. (2019). The Use of Humor in Teaching and Learning in Higher Education Classrooms: Lecturers' Perspectives. Journal of English for Academic Purposes, 40, 15-25.

5. Bates, A. W. \& Sangra, A. (2011). Managing Technology in Higher Education: Strategies for Transforming Teaching and Learning. San Francisco: Jossey Bass.

6. Bengtsson, L. (2019). Take-Home Exams in Higher Education: A Systematic Review. Educ. Sci., 9, 267.

7. Benton, S. L., \& Cashin, W. E. (2012). Student Ratings of Teaching: A Summary of Research and Literature. Manhattan, KS: The IDEA Center. http://www.theideacenter.org/sites/default/files/idea-paper_50.pdf

8. Berge, Z. L. (1995). Facilitating Computer Conferencing: Recommendations from the Field. Educational Technology 35(1), 22-30.

9. Brabazon, T. (2012). The Magic of Face-to-Face Teaching. Times Higher Education. http://www. timeshighereducation.co.uk/story.asp? storyCode $=403280 \&$ section $\operatorname{code}=26$

10. Brown, B. W. \& Liedholm, C. E. (2002). Can Web Courses Replace the Classroom in Principles of Microeconomics? The American Economic Review, 92(2), 444-448.

11. Bowen, W. G. (2013). Higher Education in the Digital Age. Princeton University Press.

12. Byram, M. (1997). Teaching and Assessing Intercultural Communicative Competence. Clevedon, UK: Multicultural Matters.

13. Canale, M., \& Swain, M. (1980). Theoretical Bases of Communicative Approaches to Second Language Teaching and Testing. Applied Linguistics, 1(1), 1-47.

14. Celce-Murcia, M., Dornyei, Z., \& Thurrell, S. (1995). Communicative Competence: A Pedagogically Motivated Model with Content Specifications. Applied Linguistics, 6(2), 5-35.

15. Chen, N.-S., Ko, H.-C., Kinshuk, \& Lin, T. (2005). A Model for Synchronous Learning Using the Internet. Innovations in Education and Teaching International, 42(2), 181-194.

16. Creasman, P. A. (2012). Considerations in Online Course Design. Manhattan, KS: The IDEA Center. http:// www.theideacenter.org/sites/default/files/idea_paper_52.pdf

17. Creswell J. (2014). Research Design, Qualitative, Quantitative and Mixed Approaches. Thousand Oaks: SAGE Publications Inc. 
An Online English Teaching Experience during Covid-19 Pandemic: Preliminary Findings

18. Creswell, J. (2012). Educational Research: Planning, Conducting, and Evaluating Quantitative and Qualitative Research. United States: Pearson/Prentice Hall.

19. Denzin N. \& Lincoln Y. (2018). The SAGE Handbook of Qualitative Research. California: SAGE Publications. 20. Doghonadze, N. \& Demir H. (2013). Critical Analysis of Open-Book Exams for University Students. Proceedings of ICERI2013 Conference, Seville, Spain.

21. Drouin, M. (2012). What's the Story on Evaluations of Online Teaching? In M. E. Kite (Ed.), Effective Evaluation of Teaching: A Guide for Faculty and Administrators (pp. 60-70). Washington, D.C.: Society for the Teaching of Psychology. http://www.teachpsych.org/Resources/Documents/ebooks/evals2012.pdf 22. Dykman, C. A. \& Davis, C. K. (2008). Online Education Forum: Part two - Teaching Online versus Teaching Conventionally. Journal of Information Systems Education, 19(2), 157-164.

23. Ellis, R. (2003). Task-Based Language Learning and Teaching. Oxford: Oxford University Press.

24. Esani, M. (2010). Moving from Face-to Face to Online Teaching. Educational Technology, 23(3), 187-190.

25. Garfield, J. (1993) Teaching Statistics Using Small-Group Cooperative Learning. Journal of Statistics Education, 1(1), DOI: 10.1080/10691898.1993.11910455

26. Garrison D., Anderson, T., \& Archer W. (2001). Critical Thinking, Cognitive Presence, and Computer Conferencing in Distance education. American Journal of Distance Education, 15, 7-23.

27. Guri-Rosenblit, S. (2018). e-Teaching in Higher Education: An Essential Prerequisite for e-Learning. Journal of New Approaches in Educational Research, 7(2), 93-97.

28. Haverkate, H. (2004). El análisis de la cortesía comunicativa, categorización pragmalingüística de la cultura española. En Bravo, D. \& Briz, A. (Eds.), Pragmática sociocultural. Estudios sobre el discurso de cortesía en español (pp. 55-65). Barcelona: Ariel.

29. Hockly, N. (2015). Developments in Online Language Learning. ELT Journal, 69(3), 308-313.

30. Hodges, C., Moore, S., Lockee, B., Trust, T., \& Bond, A. (2020). The Difference Between Emergency Remote

Teaching and Online Learning. https://er.educause.edu/articles/2020/3/the-difference-between-emergencyremote-teaching-and-online-learning

31. Instituto Cervantes, (2002). Enfoque comunicativo. https://cvc.cervantes.es/ensenanza/biblioteca_ele/diccio_ ele/diccionario/enfoquecomunicativo.htm

32. Kosak, L., D. Manning, E. Dobson, L. Rogerson, S. Cotnam, \& S. Colaric (2004). Prepared to Teach online? Perspectives of faculty in the University of North Carolina system. Online Journal of Distance Learning Administration, 7(3), (Fall 2004). State University of West Georgia, Distance Education Center.

33. Li, F. (2015). Teaching and Learning English by Doing. International Journal of Language and Linguistics, 2(5), 156-162.

34. Likitrattanaporn, W. (2017). The Development of English Language Teaching Skills for Graduate Students through the Process of Learning by Doing. English Language Teaching, 10(7), 96-103.

35. Lopera, S. (2016). Análisis sociolingüístico y pragmático de los cumplidos en una población universitaria de 
An Online English Teaching Experience during Covid-19 Pandemic: Preliminary Findings

Medellín, Colombia. (Tesis de doctorado), Universidad de Antioquia, Medellín, Colombia.

36. Lopera. S. (2014). Comparación de un curso de competencia lectora en inglés como lengua extranjera (ELE) en dos modalidades: distancia/virtual y presencial. Núcleo, 31, 147-175.

37. Lorenzetti, J. (2013.) Academic Administration - Running a MOOC: Secrets of the World's Largest Distance Education Classes. Magna Publications.

38. Merriam S. (1998). Qualitative Research and Case Study Applications in Education (2nd edition) San Francisco: Jossey-Bass Higher \& Adult Education Series.

39. MacDonald, J. (2001). On-Line learning: A Radical Pedagogy? Adults Learning, 12(5), 271--289.

40. Moore, M. \& Kearsley, G. (2012). Distance Education: A Systems View of Online Learning (What's New in Education?). Belmont, KY: Wadsworth Cengage Learning.

41. Muñoz, J. \& González, A. (2010). Teaching Reading Comprehension in English in a Distance Web-Based Course: New Roles for Teachers. Profile, 12(2), 69-85.

42. Nussbaum, M. (2002). Education for Citizenship in an Era of Global Connection. Studies in Philosophy and Education, 21, 289-303.

43. Osorno, J. \& Lopera S. (2012). Interaction in an EFL Reading Comprehension Distance Web-Based Vourse. Ikala, 17(1), 45-59.

44. Ossiannilsson, E. (2017). Leadership in Global Open, Online, and Distance Learning. In J. Keengwe \& P. H. Bull (Eds.), Handbook of Research on Transformative Digital Content and Learning Technologies (pp. 345-373). Hershey: IGI Global.

45. Paskey, J. (2001). A Survey Compares Two Canadian MBA Programs, One Online and One Traditional. The Chronicle of Higher Education. http://chronicle.com/free/2001/04/2001042601u.html

46. Picón-Jácome, E. (2013). La Rúbrica y la Justicia en Evaluación. Ikala, 18(3), 79-94.

47. Pineda Hoyos, J. E., \& Tamayo Cano, L. H. (2016). e-Moderating and e-Tivities: The Implementation of a Workshop to Develop Online Teaching Skills in In-Service Teachers. PROFILE Issues in Teachers'Professional Development, 18(1), 97-114. http://dx.doi.org/10.15446/profile.v18n1.44269

48. Ramberg, J. \& Modin, B. (2019). School Effectiveness and Student Cheating: Do Students' Grades and Moral Standards Matter for this Relationship? Social Psychology of Education, 22, 517-538. https://doi.org/10.1007/ s11218-019-09486-6

49. Reisetter, M., Lapointe, L., \& Korcuska, J. (2007). The Impact of Altered Realities:

Implications of Online Delivery for Learners' Interactions, Expectations and Learning Skills. International Journal on E-Learning, 6(1), 55-81.

50. Redmon, P. (2011). From Face-to-Face Teaching to Online Teaching: Pedagogical Transitions. Proceedings Ascile 2011 Hobart, 1050-1060.

51. Savignon, S. (2001). Communicative Language Teaching for the Twenty-First Century. In Celce-Murcia, M. (Ed.), Teaching English as a Second or Foreign Language. (pp. 13-28). Boston: Heinle \& Heinle. 
An Online English Teaching Experience during Covid-19 Pandemic: Preliminary Findings

52. Scagnoli, N. I., Buki, L. P., \& Johnson, S. D. (2009). The Influence of Online Teaching on Face-to-Face Teaching Practices. Journal of Asynchronous Learning Networks, 13(2), 115-128.

53. Shohamy, E. (2001). Democratic Assessment as an Alternative. Language Testing, 18(4), 373-391.

54. Solimeno, A., Mebane, M. E., Tomai, M., \& Francescato, D. (2008). The Influence of Students and Teachers Characteristics on the Efficacy of Face-to-Face and Computer Supported Collaborative Learning. Computers \& Education, 51, 109-128.

55. Stacey, E. \& Wiesenberg, F. (2007). A Study of Face-to-Face and Online Teaching Philosophies in Canada and Australia. Journal of Distance Education, 22(1), 19-40.

56. Stake, R. (1998). The Art of Case Study Research. Thousand Oaks: SAGE Publications, Inc.

57. Stern, B. S. (2004). A Comparison of Online and Face-to-Face Instruction in an Undergraduate Foundations of American Education Course. Contemporary Issues in Technology and Teacher Education, 4(2), $196-213$.

58. Stufflebeam, D. \& Zhang G. (2017). The CIIP Evaluation Model. How to Evaluate for Improvement and Accountability. New York: Guilford Publications.

59. Szeto, E. (2011). Transforming Learning and Teaching in Higher Education: The Impact of ICT on Pedagogy, Peer Interaction and Support in a Networked Virtual Learning Environment. International Journal of Learning, 17(11), 205-214.

60. Van den Branden, K. (Ed.) (2006). Task-Based Language Education: From Theory to Practice. Cambridge: Cambridge University Press.

61. Weiner, C. (2003). Key Ingredients to Online Learning: Adolescent Students Study in Cyberspace - The Nature of the Study. International Journal on E-Learning, 2(3), 44-50.

62. Yin, R. (2003) Case Study Research. Design and Methods, (3rd edition) Thousand Oaks, CA: SAGE Publications. 